DOI: https://doi.org/10.11144/Javeriana.upsy16-5.cibs

\title{
Crossing International Borders in Search of a Better Life: Examining the Psychological Impact of the Immigration Experience*
}

\section{Cruzando Fronteras Internacionales en Búsqueda de una Vida Mejor: Examinando el Impacto Psicológico de la Experiencia Migratoria}

Received: 11 June 2017 | Accepted: 20 August 2017

\author{
IVELISSE Torres FernándeZ \\ New Mexico University, Estados Unidos \\ ORCID: http://orcid.org/0000-0002-4573-7597 \\ Steve R. Pereira \\ New Mexico University, Estados Unidos \\ Jen Aicart \\ Universidad de Barcelona, España \\ Gonzalo Salas \\ Universidad Católica de Maule, Chile
}

\begin{tabular}{lll}
\hline a Correspondance & autor. & E-mail: \\
itfernan@nmsu.edu
\end{tabular}

How to cite: Torres, I., Pereira, S., Aicart, J., \& Salas, G. (2017). Crossing International Borders in Search of a Better Life: Examining the Psychological Impact of the Immigration Experience. Universitas Psychologica, 16(5), 1-15. https://doi.org/10.11144/Javeriana.upsy 16-5.cibs

\begin{abstract}
The focus of this paper is to discuss the cycle of migration and its psychological impact on the lives of immigrants. An overview of current migration trends, a discussion on the cycle of immigration (Casas, 2014), and its psychological consequences are presented. A qualitative phenomenological approach was utilized to analyze the stories of four immigrants, which resulted in a thematic analysis that discusses the cycle of immigration and its impact. The paper concludes with a discussion of implications, limitations, and future research.

Keywords

migration; cycle of immigration; psychological impact.

\section{RESUMEN}

El objetivo de este trabajo es discutir el ciclo de la migración y su impacto psicológico en la vida de los inmigrantes. Se presenta un panorama de las tendencias migratorias actuales, una discusión sobre el ciclo de la inmigración (Casas, 2014) y sus consecuencias psicológicas. Se utilizó un enfoque fenomenológico cualitativo para analizar las historias de cuatro inmigrantes, lo que resultó en un análisis temático que analiza el ciclo de la inmigración y su impacto. El documento concluye con una discusión de implicaciones, limitaciones y futuras investigaciones.

Palabras clave

migración; ciclo de inmigración; impacto psicológico.
\end{abstract}

\section{Introduction}

Although migration from one country to another is not a recent phenomenon, this issue has received increased 
attention due to the development of new immigration laws and policies (Migration Policy Center, 2017a); the rise of anti-immigrant sentiments (APA, 2012); and the humanitarian crisis unfolding related to thousands of immigrants who are fleeing their countries in search of a better life (Pew Research Center, 2016a). Despite the economic and financial crisis, the Organization for Economic Cooperation and Development, and the United Nations Department of Economic and Social Affairs (2013) indicated that global migration continues to rise with some 232 million international migrants living in the world today. In the United States, the immigrant population is estimated at approximately 46.6 million, the largest in the world (Pew Research Center, 2016b).

There are numerous reasons why millions of individuals make the decision to leave their country and families behind. Some migrations are planned and these individuals leave their countries seeking better jobs and economic opportunities (APA, 2012); however, for some the decision to migrate is precipitated by ongoing violence, war, poverty, and limited opportunities for advancement (Asakura \& Torres Falcón, 2013; Pew Research Center, 2016a). Regardless of the reasons to migrate, the immigration process impacts these individuals at social, cultural, financial, political, and psychological levels (Alvarado, 2008; Casas, 2014; Vilar Peyrí \& Eibenschutz Hartman, 2007). Considering the complexities involved in the migration process, the focus of this paper is to gain a better understanding of the cycle of immigration and to raise awareness on the traumas experienced throughout the migration process and its potential psychological consequences.

\section{Immigration into the United States}

According to the Pew Research Center (2016b) the U.S. has the largest number of immigrants in the world (46.6 millions), which represents $19 \%$ of all international immigrants. However, only $14 \%$ of the U.S. population is foreign born (Pew Research Institute, 2016a). In 2015, Mexican immigrants accounted for $27 \%$ of all immigrant groups, followed by China, Philippines, El Salvador, Vietnam, Cuba, Dominican Republic, Korea, and Guatemala (Migration Policy Institute, 2017a). Demographic data also indicate that in 2015, $51 \%$ of immigrants were female and had a median age of 43.9 years. In addition, $48 \%$ were naturalized U.S. citizens; $45 \%$ identified as Hispanic or Latino; and 49\% were limited English proficient (Migration Policy Institute, 2017a).

Over the past several years, the immigration from Central American countries has sparked attention and debate due to the increasing numbers of unaccompanied minors and families that are crossing the border fleeing the violence and poverty (Asakura \& Torres Falcón, 2013; Vilar Peyrí \& Eibenschutz Hartman, 2007). Data from the Migration Policy Institute (2017b) indicate that by 2015, 3.4 million Central Americans resided in the U.S., accounting for $8 \%$ of the total immigrant population. This data also reveals that $85 \%$ of Central American immigrants came from the Northern Triangle: El Salvador, Honduras, and Guatemala. Although the Central American migration to the U.S. is not a new phenomenon, other migration trends have been noted, regarding the arrival of unaccompanied minors. For example, in 2016, the U.S. Customs and Border Protection Agency intercepted 46900 unaccompanied minors and approximately 70400 families in the U.S.-Mexico border (Migration Policy Institute, 2017b). Furthermore, it has been noted that most Central American immigrants travel to the U.S. without proper documentation, making them a target of unscrupulous individuals who take advantage of them while in transit to the U.S. (Asakura \& Torres Falcón, 2013); thus, contributing to the trauma that is experienced as part of the migration process.

\section{The Cycle of Immigration}

According to Casas (2014) the immigration process can be better understood by three distinct 
stages: pre-migration, during migration, and post-migration. Casas emphasizes that all stages involve exposure to traumatic events; therefore, mental health professionals need to be aware of how to best serve the migrants' needs upon arrival to their host country. During the premigration stage, the focus is on the events that precipitated the decision to leave the country of origin. Casas (2014) and Asakura and Torres Falcón (2013) mentioned violence and extreme poverty as the main causes of immigration. Kirmayer et al. (2011) noted additional factors related to migration that can impact mental health such as economic, educational, and occupational status in the country of origin; disruption of social support, roles, and networks; trauma; and political involvement.

The second stage, during migration, focuses on the experiences that most immigrants face while in transit to their new host country (Casas, 2014). According to Casas, the living situations in some countries are precarious. And, although most are aware of the dangers they may encounter, most immigrants are still willing to risk their lives to provide a better future for their families (Townsend \& Oomen, 2015). During this stage, immigrants are subjected to multiple forms of trauma including hunger, dehydration, harsh living conditions, robberies, extortion, sexual assault, and kidnappings (Asakura \& Torres Falcón, 2013; Kirmayer et al., 2011). Repeated exposure to trauma during this stage can cause detrimental effects in the psychological wellbeing of immigrants; by the time they arrive in the host country immigrants are experiencing symptoms of depression, anxiety, and posttraumatic stress disorder (PTSD) (Achotegui, 2009; APA, 2012).

The last stage, post-migration, focuses on the issues faced by immigrants once they have arrived in the new country (Casas, 2014). According to Kirmayer et al. (2011) and Hipolito-Delgado and Mann (2012), unauthorized immigrants, refugees, and asylum seekers are at a higher risk of continuous trauma and victimization upon arrival due to their legal status, fear of deportation, being detained by immigration officials, and experiencing stigmatization by others in the community. Torres et al. (2011) pointed out additional stressors that include multiple relocations, economic hardships, having to adapt to new language, culture, and norms, long-term separations from family and friends, and xenophobia. Overall, such traumatic experiences can produce a wide range of psychological problems including suicidal ideation, acculturative stress, poor identity formation, distrust, inability to build healthy interpersonal relationships, and intergenerational conflict (Achotegui, 2009; APA, 2013).

\section{Challenges Related to the Migration Experience}

Although some immigrants will adapt well and thrive in their new country, others will face additional challenges related to the migration experience. According to the American Psychological Association Presidential Task Force on Immigration (2012) these various issues could be better understood as: acculturationbased presenting problems; trauma-based presenting problems; and discrimination, racism, and xenophobia-based problems. Acculturation interfaces immigrants with having to adapt and learn a new set of cultural norms while preserving the individuals' native culture (Berry, 1997). According to Berry (1997), the process of acculturation is complex and involves, not only learning about the new culture but also integrating it to fit a social identity prototype and daily activities. Intergenerational conflict, acculturation stress, gender role conflict, loneliness and isolation, and family conflict may surface when individuals feel the pressure to assimilate or adapt quickly to the host culture (APA, 2013; Arbona et al., 2010). Another challenge interfacing immigrants is the economic hardship that typically stems from limited job opportunities due to legal status, loss of income, or being forced to work in harsh conditions. In this regard, financial hardships have been associated with depression, anxiety, and increased risks for intimate partner violence 
(Hipolito-Delgado \& Mann, 2012; Vilar Peyrí \& Eibenschutz Hartman, 2007).

Trauma-based problems have been widely documented in the literature and these are mostly related to experiences before, during, and after the migration. Trauma-based symptoms are particularly common among refugees, asylum seekers, and undocumented immigrants. The U.S. Department of Health and Human Services [HHS] (2012) discussed that resettlement challenges increase refugees' psychiatric symptoms when moving to the U.S. These symptoms include anxiety, depression, substance abuse, PTSD, and suicidal ideation (Achotegui, 2009; APA, 2012). In addition, immigrants, particularly those who are undocumented, tend to report higher immigration stressors, lower levels of English proficiency, and separation from their families when compared to documented immigrants (Arbona et al., 2010; Hipolito-Delgado \& Mann, 2012). Finally, studies have also discussed acculturation and adaptation, discrimination and oppression, poverty and structural barriers, and development of psychological disorders as additional challenges faced by immigrants upon arrival to the new country (APA, 2013; Pumariega \& Rothe, 2010; Torres et al., 2011).

Lastly, racism, discrimination, and xenophobia have been widely discussed in the literature as contributing factors for psychological distress and adjustment difficulties. According to APA (2013) the exposure to racism and discrimination has detrimental effects in feeling welcomed (sense of belonging) and emotional well-being (feel supported and accepted by others). Most specifically, racial and ethnic discrimination have been associated with high levels of psychological distress, sadness, hypervigilance, nervousness, anxiety, depression, and suicidal ideation (Torres et al., 2011). Furthermore, racial profiling and threat of deportation negatively impacts the well-being of immigrants causing high levels of stress, fear, and anxiety (Arbona et al., 2010; Hipolito-Delgado \& Mann, 2012). In the next sections, the authors illustrate several stories of immigration with the purpose of getting a better understanding of why individuals make the choices to leave their countries behind; the challenges they faced; and the consequences of the migration process in their lives.

\section{Understanding the Immigration Experience}

\section{Purpose of the Interviews}

Our conceptualization of the cycle of immigration is based on the work of Manuel Casas (2014) who stated that individuals who migrate to other countries experience traumatic events before, during, and after their journey. These stories were part of a series of interviews conducted by one of the authors to gain a better understanding of the challenges involved in the immigration process of individuals who migrated to the U.S. from Latin America. Thus, authors stress the importance of understanding the immigration experience through a psychological, social, political, and cultural relevancy perspective (APA, 2012; Vilar Peyrí \& Eibenschutz Hartman, 2007). Note that these interviews were conducted during the harsh anti-immigration sanctions presented after President Trump's inauguration and directly aligned with reports on the raids being conducted by Immigration and Customs Enforcement (ICE), along the U.S.-Mexico border. Thus, the interviewees feared sharing their experience to avoid coming out of the shadows. For that reason, the interviews were not structured, they were completely open, but all interviewees addressed the topic of immigration.

\section{Participants and Procedure}

Participants were four self-identified Latin Americans who immigrated to the United States in search of a better life. Inclusion criteria for the narrative methodology were as follows: (1) each interviewee had to narrate their migration trek from their respective country of origin; (2) the interviewees must identify with being of Latin American origin or can trace their 
lineage to Latin American countries; and (3) fluency in speaking Spanish was also included as a criterion to capture the personal meanings and experiences of the participants journey to the U.S. The criterion for speaking Spanish was included to obtain a sample representation of current language trends and need to be used in therapeutic services. Research has found that Latinos who are less proficient in English are most likely to seek services elsewhere (Arredondo, Gallardo-Cooper, Delgado-Romero, \& Zapata, 2014). All participants met inclusion criteria and voluntarily storied their immigration experience. To protect their identities and uphold confidentiality, the participants were provided pseudonyms (Table 1).

\section{TABLE 1}

Characteristics of Participants

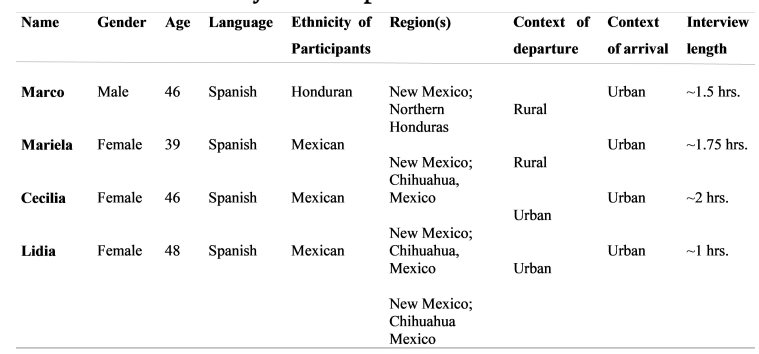

Source: own work.

The participants were recruited through snowball sampling and word of mouth. The author met with the participants in person to explain the purpose of the interviews and screened to ensure they met inclusion criteria. Interviews were audio recorded and transcribed. Following a qualitative phenomenological approach, interviews provided understanding to the lived experiences of the interviewees' immigration narratives.

\section{Thematic Analysis of Stories}

In this section, illustrative quotes are provided to discuss the context of the interviewees' narratives involving pre, during, and postimmigration experiences. Thematic analysis was conducted utilizing NVIVO software to code participants' experiences into categorical themes and subthemes (Table 2). Analysis of the interviewees' stories ultimately produced four core thematic categories: Pre-Immigration experiences in the homeland; Embarking towards a better future; The undocumented experience; and Coping through the immigration hardships.

\section{TABLE 2}

Table of Themes

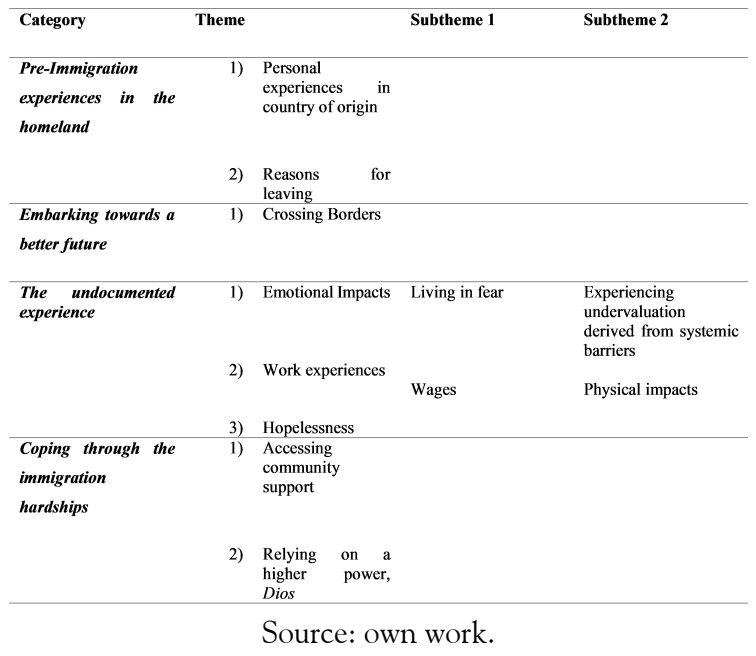

Pre-Immigration Experiences in the Homeland

The first category was Pre-Immigration experiences in the homeland. This category focused on the interviewees' personal experiences of living in their country of origin. Resulting from the environmental, social, and political contexts of living in Honduras and Mexico, the interviewees' narratives described their daily struggles before leaving to the U.S. Within this category, the interviewees discussed experiencing economic hardships, educational disparities, traumatic violence, and reasons to seek a better life by emigrating to the U.S. Contextual background of this category is discussed in the two themes, Personal experiences in country of origin and reasons for leaving.

\section{Personal experiences in country of origin}

In the first theme, Personal experiences in country of origin, interviewees discussed what their daily life was like while living in Honduras and Mexico. 
Described as hardships, interviewees revealed how life at home affected their well-being. One interviewee, Marco, described his experience growing up in Honduras as a financial struggle. He revealed, "Trabajaba, iba a la escuela, teníamos que caminar unas dos millas, creo que como unos 4 kilómetros, cada día. Íbamos con uniformes pero descalzos porque no teníamos zapatos" (March 24, 2017). Another interviewee, Mariela, discussed being a victim of various types of traumatic abuse and violence; she said, "Vivimos en casas ajenas allá en México, con familiares, con amistades, donde nos golpeaban, había abuso sexual, abuso físico, todo tipo de abuso" " (March 26, 2017). Encompassing the thematic underpinnings of this theme, Cecilia narrates her personal life experiences when she lived in Mexico. She stated:

A pesar de estar trabajando con todas mis ganas en mi centro de apoyo, económicamente era solo para sobrevivir. Era el batallar para pagar la renta, los gastos del negocio solo para mantenerlo y lo que quedaba ya para vivir yo y mis hijos." (April 2, 2017).

As shared by the interviewees, the experiences of pre-immigration trauma, while living in their country of origin, have impelled them to seek a better life in the U.S. After sharing their experiences of hardship and what their lives were like before immigration, the interviewees also revealed personal compelling reasons that impelled their decision to leave. As the introductions of these interviewees' narratives unfold, their reasons for leaving are deeply rooted in socio-cultural suffering and personal struggles.

\section{Reasons for leaving}

The beginning of the interviewees' immigration experiences encapsulated the traumatic events or hardships that occurred while living in their country of origin. Even though the societal hardships in their homeland were contributing factors in their immigration story, their actual reasons for leaving were the driving forces to emigrate. Various reasons for leaving included, economic stability, health, and promising employment opportunities. However, most salient for all, the interviewees identified needing to support their family in different capacities. Lidia stated, "Nos venimos de México porque mi hija estaba muy enferma, una enfermedad de la visión y nos dijeron que lo más que probable era que se muriera" (April 8, 2017). . Similarly, Cecilia realized that she needed to emigrate to the U. S. to support her family. She stated:

Teniendo en la cabeza de que en este país es más fácil salir adelante, yo dije bueno va a ser favorable para ayudar a salir adelante a mi madre, también para superar mi divorcio y ayudar a que mis hijos lo asimilen también poniendo un poco de tierra de por medio y en lo económico poder encontrar nuevas oportunidades. (April 2, 2017).

In this theme, interviewees shared that family was the main reason to search for a better life. However, during that process, the interviewees also indicated having to leave behind their homes, accrued valuables, and friends. Subsequently, on the quest to fulfill their hopes and dreams, the experiences of their trek to the U.S. narrate another stage of their personal immigration experience of pre-and post-crossing borderlands.

\section{Experiences of Embarking Towards a Better Future}

The second category that emerged from the interviewees' narratives was Experiences of embarking towards a better future. Within this category, the interviewees' narratives recalled their personal experiences of traveling to the U.S. The interviewees discussed means of travel, dangerous situations, survival, and confronting immigration authorities while in the border. A thematic experience in this category, crossing borders, captures the interviewees' journey to the U.S. at various points. 


\section{Crossing Borders}

In this theme, crossing borders, interviewees narrate their experiences of journeying and arriving to the U.S. Although the interviewees' trek begins at different geographical points, overlap of their experiences coincide with means of transportation, feeling displaced post-crossing, and adapting to the U.S. Within this theme, Cecilia, Mariela, and Lidia mentioned that they all emigrated from Mexico and crossed the U.S.Mexico border at different stages in their life. Although they did not have any issues being questioned by border agents and crossing checkpoints, Marco did. Marco's journey begins in Central America and retells his experiences of traveling through Mexico and finally crossing over into El Paso, Texas, U.S. He stated:

En Guatemala nos robaron, nos encerraron, pero lo que ellos querían era mordida (soborno), querían que les pagáramos para que pudiéramos continuar. Habíamos escuchado de La Bestia (un tren de carga, que suben las personas para viajar al norte), pero no se nos iba a ocurrir que íbamos a atrapar a uno. Entonces nos trepamos así sin nada y pusimos nuestra vida en sacrificio porque cuando el tren pasa, pasa...yo casi me caí, pero gracias a Dios que mi amigo pudo detenerme. Llegamos a Ciudad Juárez y allí estuvimos unos días...teníamos que pagar para cruzar y nos cruzamos a El Paso por el rio. (March 24, 2017).

The immigration experience of traveling to the U.S. was arduous for Marco. In a related but connected experience with crossing borderlands, are the feelings associated with arriving to the U.S. Adapting to the U.S. was also difficult for both Mariela and Cecilia. Mariela discussed that there were days in which they did not have anything to eat. From a psychological perspective, Cecilia felt displaced after crossing into the U.S. She stated:

Los primeros días aquí fueron totalmente difíciles, porque yo estaba aquí sin estar, mi corazón, mi mente y yo estaban en Chihuahua. Fueron días muy difíciles de adaptación al lugar, de estar buscando escuela para mi niña, estar buscando un trabajo para mí, también escuela para mí para empezar con el inglés, fueron días sumamente tristes. (April 2, 2017).

In context, the struggles of journeying to the U.S. impacted the interviewees in physical, emotional, and psychological ways. Hoping to live a better life, the interviewees encountered unexpected struggles that were incongruent with the American Dream. Mariela added, "dicen que la pobreza es en México, pero no es cierto...aquí también hay pobreza." As their narratives continue to unfold, the experiences of living in the U.S. continue to affect their life, especially when they narrate having to navigate their undocumented status.

\section{The Undocumented Experience}

In the next category, the interviewees narrate how the undocumented experience of living in the U.S. has produced a new cycle of internal and external traumatic situations that relate to emotional instability and hopelessness, difficult working conditions, economic disparities, and interfacing the United States' anti-immigration policies. Illustrative quotes of their lived experiences are captured in the themes and subthemes of this category (Table 2). An indepth look at their transition into the U.S. also exposes the impacts that the immigration process had on their overall well-being.

\section{Emotional impacts}

One of the most salient experiences of living undocumented in the U. S. was delineated in the first theme of this category, Emotional impacts. Fearing the legal risks of deportation, this experience often overwhelmed the interviewees and made them hesitant to go to work or take their children to school. Testimonies of their emotional experiences emerged within two subthemes: Living in fear and Experiencing undervaluation derived from systemic barriers. In the first subtheme, the interviewees discussed having to live in constant fear due to the 
possibility of being deported. Lidia explained how her fears also affected her family. She stated:

Tú sales cada día de tu casa para ir a trabajar, pero no sabes si vas a regresar, ese es el mayor miedo. Mis hijas tienen que ocultar nuestra situación legal a sus amigas, porque tienen miedo de que se enfaden con ellas y las amenacen con contar sobre nuestra situación. Sientes mucha impotencia, mucha tristeza. En cualquier momento, en cualquier lugar te pueden parar y pedirte tu documentación. "(April 8, 2017).

A closely related subtheme, but presented in a different affective context is Experiencing undervaluation derived from systemic barriers. In this theme, the interviewees discussed feeling worthless and belittled in the U.S. society. According to Cecilia, the anti-immigration policies made her feel like she was nobody. She stated, "aquí te hacen sentir nada, aquí no eres nadie, aquí vas a empezar de cero al igual que empiezan todos los inmigrantes y yo me sentí desplazada por el idioma y por no tener mi numerito de seguro social" (April 2, 2017). Paralleled to Cecilia's experience, Mariela stated:

Nos tienen en las sombras, saben que estamos aquí, pero nos ignoran. No nos dan ningún derecho, nomás reciben todos los impuestos, todo el beneficio. Yo no tengo las mismas oportunidades que una persona, o sea hago lo mismo que cualquier otra persona legal pero no tengo las mismas oportunidades que ellos. " (March 3, 2017).

The feelings shared by the interviewees reveal emotional experiences that have defined their undocumented experiences. In addition, Lidia stated, "Sientes la discriminación y por eso también mis hijas lo ocultan a casi todo el mundo. Pero somos personas normales, trabajadores, no hacemos nada malo." (April 8, 2017). As their experiences continue to affectively damage their well-being, the interviewees realize that their negative experiences also impact their work duties and responsibilities.

\section{Work experience}

Although the interviewees were hoping to seek a better life in the U.S., they quickly learned that they continue to be subject to trauma, especially in employment settings. In this theme, the interviewees' narratives offer a first-person account of how their job experiences were heavily impacted by earning unfair wages and feeling the physiological impact of working within arduous conditions. Contextual examples of their experiences are captured in the two emerging subthemes of this section: Wages and Physical impacts.

\section{Wages}

In the first subtheme, wages, all the interviewees discussed working in difficult jobs that were often underpaid. According to Cecilia, aside from earning little money, she was also scorned for damaging property. She narrates, "en la semana solo había sacado 40 dólares en total porque, en una de las estufas, que yo tallé demasiado, se ralló y se tuvo que comprar carátula de la estufa. Me trató como si yo fuera la basura." (April 2, 2017) In Mariela's work experience, she discusses being robbed by her employers through unreported tax deductions. She stated:

Como saben que no tienes papeles, te quitan taxes, los impuestos, pero no te los reportan, o sea no más te los están robado, porque dicen que ellos tienen que reportar pero si no les entregas un seguro social no hay manera de que ellos lo reporten, y claro que te pagan el mínimo por no tener papeles y por ser mujer. Me da tristeza porqué, estoy haciendo lo mismo que los demás y a mi esas cosas me afectan. (March 26, 2017)

In this subtheme, the interviewees presented how their earned income is directly affected by their undocumented status in the U.S. Most importantly, the experience of working in the U.S. without documentation presented an overarching issue that caused the interviewees to feel undervalued. Although the interviewees felt that they should have earned the same 
income as their co-workers, it was clear that their undocumented status would not remedy the situation and, in the end, would not qualify them to work in professional settings. Mariela added, "yo tengo la misma capacidad de cualquier otra persona de correr un negocio de contabilidad, de administración de empresas, no lo puedo hacer porque no puedo ir a trabajar para una empresa grande porque no tengo papeles." (March 26, 2017)

\section{Physical impacts}

Due to their undocumented status, the interviewees quickly learned that they would have to conform to working devalued employment opportunities. In this subtheme, Physical impacts, the interviewees discuss the types of jobs they held and how it affected them physically. At the age of 15, Marco described the various types of jobs that, according to him, not many would sign up for. He stated, "Llegué a trabajar en la cebolla, que es uno de los trabajos más pesados aquí en EEUU. No cualquiera lo hace." (March 24, 2017r) Mariela corroborated Marcos' experience when she stated, "Pues es lo más pesado que yo he hecho era levantar la lechuga congelada. Mis manos no las sentia ya de lo congeladas que estaban." (March 26, 2017) Encompassing the experience of working in difficult conditions in this subtheme, Cecilia narrated:

Creo que aguanté lo más que pude, fue un mes y medio, en un trabajo que me estaba acabando físicamente. Fue una etapa muy difícil en mi vida, tanto que mis manos estaban con moretones y muy lastimadas. (April 2, 2017)

Seemingly, the physical consequences of working in devalued jobs have shattered their hopes of living a better life away from their homeland. Although they never imagined the hardships they would encounter, their struggle to keep going was derived from personal survival. And, in the direst situations of their undocumented experience, the interviewees would often feel like giving up and return to their country of origin.

\section{Hopelessness}

After suffering economic disadvantages and enduring harsh working conditions, the interviewees underscored a major theme that tested their decision to stay or leave the U.S. In this theme, Hopelessness culminates the undocumented experience of this category and illustrates the interviewees' experiences of wanting to go back home. Within this theme, there were various critical points of their undocumented experience that compelled them to give up. For Marco, his turning point was when he was traveling north to the U.S. Marco stated, "Caminamos mucho hasta agarrar un bus que nos llevó hasta la Ciudad de México. Allí yo ya quería renunciar, porque ya había sufrido mucho." (March 3, 2017) Furthermore, Cecilia recalled moments of despair when she realized that her experience in the U.S. were not what she expected. Cecilia explained:

Yo estaba sintiéndome muy sola, muy desprotegida, muy a la deriva, yo le hablo a mi hermana y le digo, sabes que yo ya me vuelvo a Chihuahua. Fueron momentos tan frustrantes en mi vida que yo fácil hubiera podido renunciar a todo y regresarme a Chihuahua, a México, a empezar de cero otra vez porque allí ya no tengo nada tampoco. Te sientes que no eres ni de aquí ni de allá cuando estás en una situación así. (April 2, 2017)

The closing of this theme and category presented compelling narratives that gave insight into how the interviewees wanted to end their struggles by contemplating the idea of returning home. Unfortunately, their hardships of having to navigate the harsh experience of being undocumented in the U.S. caused them to feel an overwhelming amount of emotional, physical, and psychological aguish. Beyond the individual personal events, although closely related, their stories also affected their loved ones. However, during despair, the interviewees shared glimpses of hope that seemingly eased their suffering. In 
the final category, the interviewees discussed accessing support systems that ultimately helped them adapt to their undocumented experience of living in the U.S.

\section{Coping Through the Immigration Hardships}

Throughout the above-mentioned categories, the interviewees presented how their trajectory to reach the U.S. was a difficult experience. Premigration trauma, experiencing trauma during their journey, and confronting new traumatic realities after crossing the U.S.-Mexico border, the interviewees interfaced many barriers that inflicted tremendous pain. Even though their struggles occurred daily, the interviewees utilized their proximal support systems to overcome their hardships. In this category, coping through the immigration hardships, the interviewees recounted how they managed adversity, which resulted in the two themes: Accessing community support and Relying on a higher power, Dios.

\section{Accessing community support}

The immigration cycle, endured by the interviewees, caused them to confront added personal sufferings during their transition to the U.S. Amid intense hopelessness; the interviewees alleviated their pains by Accessing community support systems. In this theme, the interviewees' narratives discussed how finding support within their surroundings assisted them in moving forward with their lives in the U.S. According to Marco, a local teacher he met through his traveling mate assisted him with finding a place to stay in the U.S. Marco stated, "Después de unas dos semanas, el maestro me llevó a su casa con él y su familia y me dijo, va a empezar usted a vivir con familias americanas, como parte de un 'programa', como asilo" (March 24, 2017). Relatedly, Cecilia received support from a community agency, which for the first time, made her feel invaluable. Cecilia stated:
Ya no me sentí como la mujer inmigrante ilegal en este país, sino que en estas oficinas me acogieron y me recibieron como la mujer que yo soy sin tener en cuenta mi nacionalidad o mi estatus legal en este país, sino que valoraron quién yo soy, a mí me encantó eso. (April 2, 2017)

The support that the interviewees received from the community allowed them to experience the treatment they had initially hoped for in their post-immigration experience. In these moments, the interviewees alleviated some of their hardships and managed other pressing concerns. Most importantly, they finally felt that their worries began to subside after placing their trust in a higher power, Dios.

\section{Relying on a higher power, Dios}

In the last theme, relying on a higher power, Dios, the interviewees make numerous references to God as their main source of spiritual support when facing adversity amid their immigration experiences. At varying points of their narratives, all the interviewees sought God's assistance to help them make sense of their taxing experiences. Marco recalled having to live through the dangers of emigrating to the U.S. His plea to God was, "Clamé mucho a Dios y le dije, dame una oportunidad más, que no he venido de tan lejos a morir así." (March 24, 2017) In Cecilia's prayers, she asked God to guide her through tumultuous experiences that debilitated her overall wellbeing. She stated:

Señor, perdóname porque a veces pierdo la fe y quisiera dejar todo, aventar la toalla y dejar de creer lo que has prometido en mi vida, pero una vez más decido creerte y aquí sigo. Señor no más ayúdame y dame fuerzas para enfrentar lo que viene y aprender las lecciones que tú me quieres dar con estas experiencias. (April 2, 2017)

Aside from accessing community support, this theme also highlighted the interviewees' engagement with personal spiritual practices. Relying on God for help played a major role in the interviewees' well-being. Seemingly, consulting with God also influenced the decision to stay 
or leave the U.S. Mariela expressed, "Le pedí a Dios, guíame, dime si me debo de ir, dame una señal si me debo de ir de aquí." (March 26, 2017) The interviewees' narratives considered God to be an integral part of their experience and remained a constant spiritual value that assisted them throughout their immigration experience.

The interviewees' experiences in this section narrated the traumatic stages of emigrating to the U.S. that included: Pre-Immigration experiences in the homeland; Embarking towards a better future; the undocumented experience of living in the U.S. and Coping through the immigration hardships. The reflections of the interviewees specifically homed on the most critical moments of their immigration journey to the U.S. As their stories intertwined, the interviewees' undocumented experiences presented compelling details on the personal sufferings that nearly impelled them to surrender and return home. Eventually, access to support and pleas for spiritual guidance opened the possibility to realize their hopes to live a better life in the U.S.

\section{Discussion}

\section{Pre-Immigration Experiences in the Homeland}

The first category, pre-immigration experiences in the homeland, included two main themes. The first theme, Personal experiences in the country of origin, involved the interviewees' memories of living in their country of origin and the hardships they experienced. Marco, Cecilia, and Mariela discussed how economic hardships, exposure to abuse and trauma, and extreme poverty were salient aspects of their lives in Mexico and Honduras. These findings are paralleled to those reported in the literature that examines emigration and the challenges experienced by these individuals in their country of origin (APA, 2012; Asakura \& Torres Falcón, 2013; Vilar Peyrí \& Eibenschutz Hartman, 2007).

In second main theme, reasons for leaving, the interviewees revealed the reasons that precipitated their decision to emigrate to the U.S. Some of these factors included wanting to provide a better life for their families, economic stability, overall good health, and promising job opportunities. Needing to support their families and providing them with better socio-cultural opportunities is also a theme highlighted in the literature (Torres et al., 2011). Unfortunately, some individuals leave their country of origin with false impressions. These individuals did not imagine how the hardships would affect them during transit and upon arrival to the U.S. However, as conditions in their country of origin worsen, evidence suggests that most migrants are aware of the risks they might face (Townsend \& Oomen, 2015) or the violence and discrimination they will experience throughout their journey (Asakura \& Torres Falcón, 2013).

\section{Embarking Towards a Better Future}

The second category, embarking towards a better future, included one main theme, crossing borders. This category discussed the interviewees' personal experiences while traveling to the U.S. The theme, crossing borders, captures the challenges experienced during the journey to the U.S. The stories revealed that the interviewees came to the U.S. from different routes (Honduras-Mexico-US; Mexico-US) and used different means to get here (riding La Bestia; crossing the border with help of coyotes; crossing border checkpoint). Regardless of how they got here, it was evident that the experience was very difficult and produced high levels of stress, anxiety, and despair (Achotegui, 2009; Alvarado, 2008). This was relevant for Marco, who revealed that during his journey he was exposed to environmental hardships, experienced hunger, and was a victim of extortion among other things. The experiences shared in these stories are aligned with those of other immigrants. While in transit to the U. S., most immigrants suffer the effect of battling heat, not having enough food or water, traveling hundreds or thousands of miles by foot or train, some threatened by others (Asakura \& Torres Falcón, 2013; Casas, 2014). However, for Mariela, Cecilia, and Lidia their hardships started upon arrival, as they 
struggled to adapt to the new country and started experiencing racism and discrimination.

\section{The Undocumented Experience}

The third category, the undocumented experience, included three main themes and four subthemes. This category discussed the interviewees' experiences arriving to the U.S. Upon arrival, Marco, Cecilia, Lidia, and Mariela continued to be exposed to traumatic experiences. In this cycle, the experiences were related to emotional instability and hopelessness, difficult working conditions, economic disparities, and interfacing the United States' anti-immigration policies. The first theme, emotional impacts, discussed the emotional toll these experiences have in the personal and familial life. Within this theme, two subcategories emerged: living in fear and experiencing undervaluation derived from systemic barriers. These two subcategories reflect the interviewees' fears of being deported and how their newfound status in this country make them feel hopeless and belittled; feelings that impacted their emotional well-being. In this regard, the psychological impacts of immigration have been widely discussed in the literature noting that during the process of adapting to the host culture, immigrants may experience depression, anxiety, stress, and PTSD (Achotegui, 2009; Vilar Peyrí $\&$ Eibenschutz Hartman, 2007).

For undocumented immigrants, the migration experience can be highly stressful due to their legal situation. As the literature points out, undocumented immigrants face unique psychological challenges that negatively impact their emotional well-being such as discrimination and prejudice, change in gender roles, marginalization, and threats of deportation (Hipolito-Delgado \& Mann, 2012). Another important issue relates to the anti-immigrant sentiments that many immigrants faced upon arrival to their new country. In this regard, migrants face numerous barriers including racism and discrimination resulting from language barriers, difficulty finding housing, accessing services, and unfair work conditions (APA, 2013; Torres et al., 2011).

These challenges are parallel to the second theme, work experience, which discusses the interviewees' difficulties of finding jobs because of their undocumented status, earning low pay for their job duties, and working in harsh conditions which impacts their ability to earn money (wages) and cause physical ailments (physical impact). However, even though the immigrants in these stories endured multiple challenges in their adjustment to the new country, they never gave up and remain hopeful amidst adversity. The interviewees' positive attitude and desire to provide for their families, is a salient reflection of their resilience (APA, 2012).

\section{Coping Through the Immigration Hardships}

The final category, coping through the immigration hardships, included two main themes. The first theme, accessing community support, involved interviewees' experiences of receiving support from local individuals and community agencies in their new hometowns. However, prior to receiving support, the interviewees had severely been affected by constant traumas of living in the U.S. Paralleled to Casas' (2014) discussion of experiencing trauma in a new country, the interviewees were subjected to work in harsh conditions, discrimination, and lived in constant fear of deportation. Such traumatic events haunted their daily experience of living in the U.S. To their surprise, however, none of the interviewees expected to encounter moments of hope and change. Although not the norm, in the undocumented experience of those who come to the U.S., the interviewees were able to access opportunities that slowly began to change their outlook of a better future and alleviate the stressors of having to hide from immigration authorities (Hipolito-Delgado \& Mann, 2012). And, even though the interviewees did not directly mention that their trauma in a new country produced psychological implications, their stories of accessing support illustrated a renewed source of hope. 
The second and last major theme in this category, relying on a higher power, Dios, encompasses the ways in which the interviewees used spirituality to cope with their immigration hardships while traveling and living in the U.S. Throughout their narratives, Cecilia, Lidia, Mariela, and Marco mentioned Dios to be their ultimate guide amid several stages of their immigration experiences. Although not an atypical practice among Latin and Central Americans, accessing various forms of spirituality during traumatic events, helps alleviate psychological ailments (McNeill \& Cervantes, 2008). Aligned with the interviewees' spiritual beliefs, relying on a higher power allowed them to endure and make meaning of their traumatic experiences. Furthermore, by relying on spirituality, as a Latino cultural core-value and psychological intervention to manage traumatic experiences, the interviewees alleviated some of their stressors (Pereira \& Torres Fernández, 2016).

\section{Implications for Mental Health Professionals}

As discussed in the paper, the migration process is complex (Casas, 2014; Townsend \& Oomen, 2015) and in many cases psychologically painful (Achotegui, 2009; Alvarado, 2008). Practitioners are encouraged to become more proactive in utilizing culture-centered interventions, especially when considering the increase of immigrant populations and the complexities of issues involved in the migration process (APA, 2013). Although much of the scientific literature calls for the provision of services that acknowledge the specific nuances of these populations, there is a pervasive tendency in the field to utilize Western/Euro-centric treatment models (Sue \& Sue, 2013). This is problematic because these models are very individualistic; thus, denying the specific social, political, and cultural context that impacts client's experiences and well-being (Organista, 2007).

When examining the psychological and emotional needs of the immigrant populations, it is important to use an inclusive, strengthbased approach that takes into consideration the multiple forces or contexts that interact in the lives of immigrant clients. In this regard, the American Psychological Association, Presidential Task Force on Immigration (2013) developed guiding principles that are very helpful in understanding the needs and specific nuances of immigrant clients. The guiding principles call for (a) the use of an ecological perspective; (b) the use of evidence-based practices; (c) the provision of culturallycompetent services; (d) partnering up with community-based organizations; and (e) the incorporation of a social justice framework. While the use of ecological frameworks recognize the complexities of human experience and the role of the multiple systems that impacts individual lives; it also acknowledges that behavior does not occur in a vacuum, but is affected by the larger culture and society (Alvarado, 2008). In addition, the use of evidence-based practices emphasizes the need to incorporate approaches that have been effective when working with certain populations (APA, 2013). However, it is important to note that when incorporating evidence-based practices, these may need to be modified or adjusted to be culturally congruent with racial and ethnic minority groups. Lastly, the incorporation of social justice principles and communitybased approaches highlight the importance of collectivistic values; the recognition that communities are resilient and have many strengths; and the importance of advocating for equality and fair treatment (Pereira, Ramos, \& Torres Fernández, 2017; Torres Fernández, 2015).

\section{Limitations and Future Directions}

Several limitations are noted as we reflect on the interviewees' immigration experience. First, there were a limited number of interviews; therefore, generalizations of other immigrant experiences should not be contextually applicable to all. Although the narratives gathered from the participants allowed us 
to make connections regarding the cycle of migration and its psychological impact on the lives of these individuals, having a larger sample would have facilitated a more in depth discussion regarding specific factors involved in the migration process. In doing so, potential findings of how immigrants make sense and cope with their immigration experience could address psychological stressors. Another potential limitation is related to the use of an open interview format vs. a semi-structured interview process. Although the open format fit very well with a constructivist approach, it limited our ability to delve into specific questions that could have shed some light on the context of their migration process, psychological impacts, and coping strategies. In addition, asking participants for specific recommendations they might have for mental health professionals who wish to or are currently working with the immigrant population would have been helpful. Considering the integration of future research, it is recommended that the patterns of immigration should not be confined to the U.S.-Mexico borderland perspective. Instead, the immigration experience should also be scrutinized on a global scale to obtain a more holistic understanding of the psychological impact it has on diverse populations.

\section{Acknowledgements}

This project was part of a larger study titled $\mathrm{La}$ Frontera Cósmica: Coining fronterizo identity and spiritual holism in the southwest borderland, which was approved by New Mexico State University IRB Office (Protocol Number 13560). This is a research article that follows a qualitative phenomenological methodology.

\section{References}

Achotegui, J. (2009). Migración y salud mental. El síndrome del inmigrante con estrés crónico y múltiple (síndrome de Ulises). Revista Zerbitzuan, 46, 163-171.
Alvarado, R. (2008). Salud mental en inmigrantes. Revista Chilena de Salud Pública, 12(1), 37-41.

American Psychological Association, Presidential Task Force on Immigration. (2012). Crossroads: The psychology of immigration in the new century. Washington DC: Author.

American Psychological Association. (2013). Working with immigrant-origin clients: An update for mental health professionals. Washington DC: APA.

Arbona, C., Olvera, N., Rodriguez, N., Hagan, J., Linares, A., \& Wiesner, M. (2010). Acculturative stress among documented and undocumented Latino immigrants in the United States. Hispanic Journal of Behavioral Sciences, 32(3), 362-384. http:// doi.org/10.1177/0739986310373210

Arredondo, P., Gallardo-Cooper, M., DelgadoRomero, E. A., \& Zapata, A. L. (2014). Culturally responsive counseling with Latinas/ os. Alexandria, VA: American Counseling Association.

Asakura, H., \& Torres Falcón, M. (2013). Migración femenina centroamericana y violencia de género: Pesadilla sin límites en Zona Franca. Revista del Centro de Estudios Interdisciplinario sobre Mujeres, $21(22), 75-86$.

Berry, J. W. (1997). Immigration, acculturation and adaptation. Applied Psychology: An International Review, 46(1), 5-34.

Casas, M. (2014). Caution: Immigration can be harmful to your mental health. Latino/a Psychology Today, 10(1), 6-9.

Hipolito-Delgado, C., \& Mann, J. (2012). Illuminating the shadows: Sociopolitical and counseling needs of undocumented Mexican immigrants. Interamerican Journal of Psychology, 46(3), 395-402.

Kirmayer, L. J., Narasiah, L., Munoz, M., Rashid, M., Ryder, A. G., Guzder, J., ... \& Pottie, K. (2011). Common mental health problems in immigrants and refugees: General approach in primary care. Canadian Medical Association Journal, 183(2), 959-967. 
McNeill, B. W., \& Cervantes, J. M. (Eds.). (2008). Latina/o healing practices: Mestizo and Indigenous perspectives. New York, NY: Routledge.

Migration Policy Institute. (2017a). Frequently Requested Statistics on Immigrants and Immigration in the United States. Retrieved from http://migrationpolicy.org/print/1585 6\#.WSb2PRPyvOQ

Migration Policy Institute. (2017 b). Central American Immigrants in the United States. Retrieved from http://migrationpolicy.org/article/cent ral-american-immigrants-united-states

Organista, K. C. (2007). Solving Latino psychosocial and health problems: Theory, practice, and populations. New Jersey: John Wiley \& Sons, Inc.

Pereira, S. R. \& Torres Fernández, I. (2016). Sanando el espanto de la opresion: Celestial healing as a curative factor for Latinxs. Latina/o Psychology Today, 3(2), 22-26.

Pereira, S. R., Ramos, S. L., \& Torres Fernández, I. (2017). Semillas de empoderamiento en la frontera: Seeds of empowerment in the borderland. Latino/a Psychology Today, 4(1), 14-17.

Pew Research Center. (2016a). International migration: Key findings from the U.S., Europe and the world. Retrieved from http://www.pe wresearch.org/fact-tank/2016/12/15/intern ational-migration-key-findings-from-the-u -s-europe-and-the-world/

Pew Research Center. (2016b). 5 facts about the U.S. rank in worldwide migration. Retrieved From http://www.pewresearch.org/5factsab outtheusrank

Pumariega, A. J., \& Rothe, E. (2011). Leaving no children or families outside: The challenges of immigration. American Journal of Orthopsychiatry, 80(4), 505-515.

Sue, D. W., \& Sue, D. (2013). Counseling the Culturally Diverse: Theory and Practice, Sixth Edition. Hoboken, New Jersey: John Wiley \& Sons, Inc.

The Organization for Economic Cooperation and Development (OCDE) and United Nations Department of Economic and Social Affairs
(UNDESA). (2013). World Migration in Figures. Retrieved from http://www.oecd.or g/els/mig/World-Migration-in-Figures.pdf

Torres, H. L., O'Conor, A., Mejia, C., Camacho, Y., \& Long, A. (2011). The American dream: Racism towards Latino/ as in the U.S. and the experience of trauma symptoms. Interamerican Journal of Psychology, 45 (3), 363-368.

Torres Fernández, I. (2015). A social justice perspective on children's mental health: A borderlands view. Communique, 43(6), 1, 24-26.

Townsend, J., \& Oomen, C. (2015). Before the boat: Understanding the migrant journey. Brussels: Migration Policy Institute Europe.

United States Department of Health and Human Services, The Office of Minority Health. (2012). Mental health and Hispanics. Retrieved from http://minorityhealth.hhs.gov/templa tes/content.aspx?lvl $=3 \&$ lvlID $=9 \& I D=64$ 77

Vilar Peyrí, E., \& Eibenschutz Hartman, C. (2009). Migración y salud mental: Un problema emergente de salud pública. Revista Gerencia y Salud, 6(13), 11-32.

\section{Notes}

* Research article 